\title{
Effect of Season on Catch rate, Diet and Aspects of Reproduction of Clarias gariepinus (Teleostei: Clariidae) in a Tropical Waterfalls
}

\author{
Gabriel U. Ikpi ${ }^{1}$, Adetola Jenyo-Oni ${ }^{2}$, Benedict O. Offem ${ }^{3, *}$ \\ ${ }^{1}$ Department of Fisheries and Aquatic Science, Faculty of Agriculture and Forestry, Cross River University Of Technology, Obubra \\ Campus, Cross River State, Nigeria \\ ${ }^{2}$ Department of Wildlife and Fisheries Management, Faculty of Agriculture and Forestry, University of Ibadan, Nigeria \\ ${ }^{3}$ Department of Fisheries and Aquatic Science, Faculty of Agriculture and Forestry, Cross River University Of Technology, Obubra \\ Campus, Cross River State, Nigeria
}

\begin{abstract}
The African catfish Clarias gariepinus (Burchell 1822) are highly valued food-fish and are among the dominant fishes of commercial catches in major rivers in Africa. The aim of the present study was to provide data on reproductive biology, diet habits, length-weight relationship and condition factor that can be useful for conservation and propagation of this species. The study was carried out over 24 months in the three reaches of the $200 \mathrm{~km}$ - long of Agbokum waterfalls, Nigeria. The influence of season on catch rate, reproduction and diet was determined from catch samples. There was a significant difference in the catch rate between the dry and wet seasons. Peak catch occurred during the early and late rains. The peak breeding period was June - July. The fish were omnivorous, with trophic flexibility being related to food availability. The condition of the fish was better downstream of the waterfalls than the other two reaches, but declined during dry season and improved during early and late rains. Therefore downstream reaches during wet season are significant in the fisheries studies of waterfalls
\end{abstract}

Keywords Waterfalls, Catch Rate, Fecundity, Diet Habit, Condition Factor, Season

\section{Introduction}

Clarias gariepinus belong to the family Clariidae and occur in most freshwater bodies of South East Asia and Africa where they constitute a significant component of the catches. The highest genetic diversity is found on the African continent where some 14 genera have been reported[1] against two in Southeast Asia. They have high market value in Nigeria and the world at large, and a vital source of vitamins and protein which are highly digestible[2]. They are very strong and easily adapted to their environment; they are inexpensive in term of the cost of production when cultured. They live in freshwater lakes, rivers, swamps, as well as human-made water bodies, such as ponds or even urban sewer systems[3]. Clarias gariepinus commonly refer to as African Catfish is a large, eel-like usually of dark gray or black coloration on the back, fading to a white belly. It has a slender body, a flat bony head and abroad terminal mouth with four pairs of barbell[4].

In both continents Clarias gariepinus are of great

\footnotetext{
* Corresponding author:

benbeff06@yahoo.com (Benedict O. Offem)

Published online at http://journal.sapub.org/als

Copyright $(\underset{2}{ } 2012$ Scientific \& Academic Publishing. All Rights Reserved
}

economic importance as food fish and vital in the sustainability of aquaculture due to their attributes[5] which include; abil ity to withstand handling stress, disease resistance, high growth rate, yield potential, fecundity and palatability[6]. There is acute reduction of these species in inland waters in Nigeria because of the over-exploitative nature of indigenous fishers that destroys the habitat and fisheries resources[7]. Knowledge on their biology is important for rational utilization of stock. An effort by the Nigerian government to conserve and propagate these species through fisheries regulation and fish breeding is being hindered because of the little information available on the ecology of these species in Nigerian waters. Most of the research works are limited to the reproductive biology of $C$. gariepinus [8, 3, 10-13]. No work had been undertaken on the ecological studies of $C$. gariepinus in Waterfalls. This paper therefore provides information on the ecological influence of season on the distribution catch rate, diet and reproduction of $C$. gariepinus in waterfalls of Southeastern Nigeria. These data will form the bases for management strategy of this species in waterfalls in Africa.

\section{Materials and Methods}

Study area. The study area is Agbokim Waterfalls in 
Cross River State, Nigeria (Figure 1).

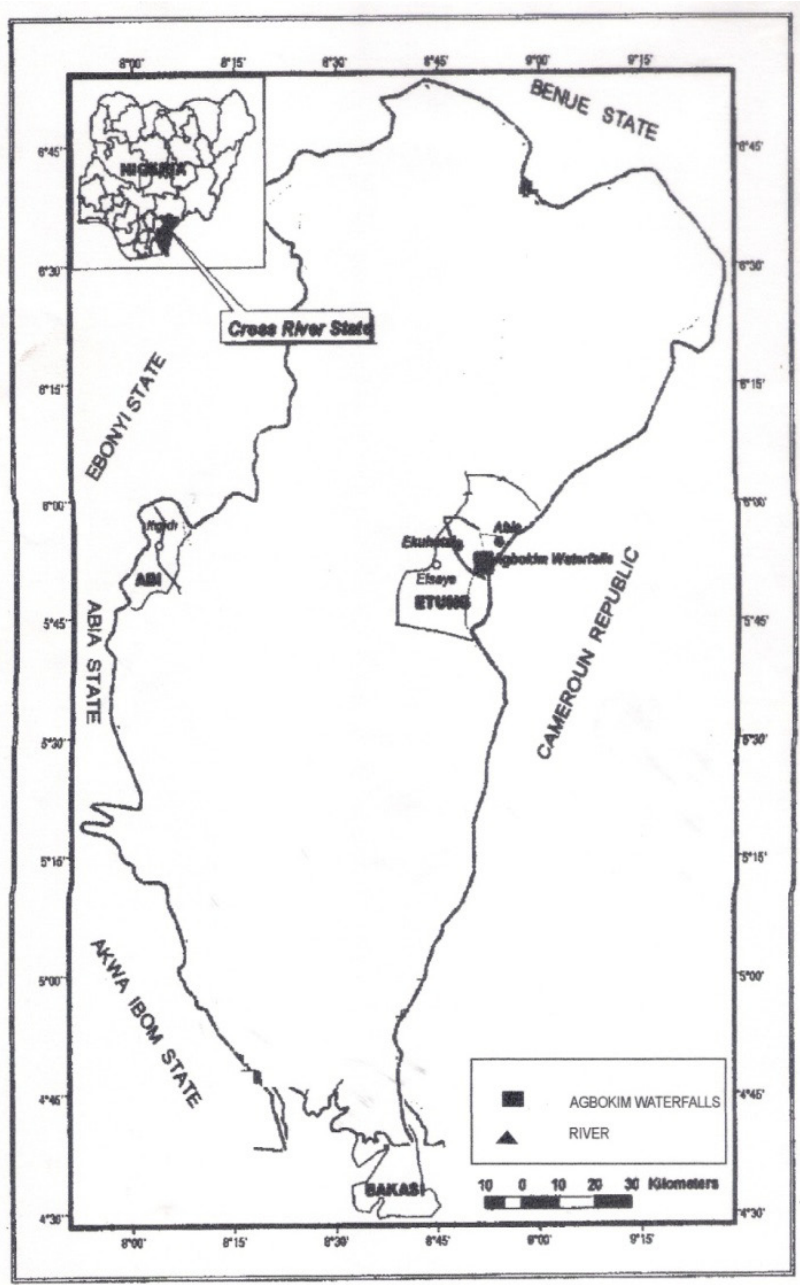

Figure 1. Map of Cross River State showing Agbokim Waterfalls

Agbokim Waterfalls is located in latitude $5^{0} 59^{\prime}$ North and longitude $8^{0} 45^{\prime}$ East. It is bounded in the West by the Cross River and in the North by the Cameroon high forests. The climate of Agbokim Waterfalls is the tropical hinter-land type, with wet (May-November) and dry (December-April) seasons. Mean annual temperature ranged between $20^{\circ} \mathrm{C}$ and $32^{\circ} \mathrm{C}$ and annual total average rainfall, from $1450 \mathrm{~mm}$ to $3015 \mathrm{~mm}$. The vegetation is the rainforest type with Soil consisting of deep laterite and dark fertile, clayey and loamy soils. Agbokim Waterfalls is drained by two small rivers, Ekue and Bakue, which are tributaries of the Cross River system. Of ecological importance are numerous small pools and swamps which are found along the length of the waterfalls. The high annual discharge and rainfall of the Agbokim Waterfalls provide excellent buffers against natural ecological stresses such as drought[14] which can lead to the loss of important fish taxa. The total length of the waterfalls is $6817.73 \mathrm{~m}$. For the purpose of this study the waterfalls is divided into upstream, midstream (region of water fall) and downstream reaches. Upstream is close to cocoa farms with high forest cover along its shoreline and moderately fast water currents during the dry season and very fast water current during the wet season. Midstream has heavy water turbulence during the wet season and moderate water turbulence during the dry season with shoreline sparsely shaded with vegetation while downstream water current is low with an extensive wide area. The length upstream is $2003.13 \mathrm{~m}$, midstream $807.42 \mathrm{~m}$ and downstream $4007.18 \mathrm{~m}$. Mean width upstream, midstream and downstream are $26.34 \pm 2.2 \mathrm{~m}$, $32.84 \mathrm{~m}$ and $40.52 \pm 10.9 \mathrm{~m}$, respectively. Upstream mean height is $31.87+3.4 \mathrm{~m}$ while the depths upstream and downstream are dependent on variation of the volume of water from rainfall and water discharge.

Three sampling sites were selected along the length of the water falls, with one site occurring in each of the reaches. Fish samples were collected once every month from 10 randomly selected fishers from each reach by day (0830-1200hours) and night (2400-0600 hours). The fishing gears comprised mainly seine net $(10-34 \mathrm{~mm}$ stretched mesh size) and gill net (22-76mm stretched mesh size). Distribution pattern of the fish in the study area was investigated in the field. Fish samples were preserved in $10 \%$ formalin prior to laboratory examination. In the laboratory, data obtained from each fish included; length, weight, sex, fecundity and food records. Standard length (SL) and total length (TL) were measured to the nearest $0.1 \mathrm{~cm}$ and weighed (wt) to the nearest $0.1 \mathrm{~g}$. Samples were identified using FAO Species Identification Sheet[15] and other authors[16, 17, 18] and sexed by visual observation of the gonads.

Specimens for diet studies, were dissected and their guts removed immediately after capture and stored in formaldehyde solution (4\%) until the contents were analyzed[19]. Gut analysis was later carried out, food items identified to the lowest possible taxon and analysed quantitatively for percentage composition by number $(\mathrm{N})$ and frequency of occurrence (FO)[20, 21]. Percent composition by number is the percentage of the number of food items examined accounted for by selected taxa. Frequency of occurrence describes the percentage of fish with non-empty gut that contained at least one of a selected food item. In calculation unidentified food items were not used.

Analysis of fecundity was limited to the peak spawning period (May-July) and only ripe female fish (494) were used for the estimation. Ovaries were removed from body cavity of each fish, weighed and preserved in Gilson fluid[22]. This method of preservation hardened the eggs, break down ovarian tissues and liberate the eggs. Ovaries of each fish were preserved for seven days before the eggs were counted. The preserved ovaries were washed to remove the preservative. Eggs were separated from tissue and placed on filter paper to remove excess water before being weighed using metler P 1210 chemical balance. Only the largest eggs $(2.0-3.0 \mathrm{~mm})$ in each sample were used for fecundity estimation. Eggs in a l-gram sub-sample were counted. Counting was done for five similar sub samples. The mean number of eggs in the five sub samples gave the number of eggs per gram of weight. Fecundity was calculated by multiplying the total weight of eggs by the number of eggs per gram weight. Relative fecundity $(\mathrm{RF})=$ No. of eggs per unit length $(\mathrm{cm})$

\section{Data treatment}


Fecundity - length and fecundity-weight relationships were determined using the expression by King (1991).

$$
\mathrm{F}=\mathrm{ax}^{\mathrm{b}}
$$

$\mathrm{F}=$ absolute fecundity, $\mathrm{x}=$ independent variables (body weight, total length). $a=$ scaling constant representing the intercept, $b=$ allometric coefficient both of which were evaluated by least squares regression analysis using log transformed data; $\log F=\log a+b \log x i$. Length at first maturity was worked out by plotting the percentage of mature fish against their lengths. Lengths at which $50 \%$ of the females were mature, was considered length at first maturity. It was calculated by an equation generated from the graph. Gonad cycle was determined from changes in gonad weight, as shown by Gonado-somatic Index (GDI) calculated by expressing the gonad weight as percentage of body weight[23].

Fulton's condition factor (CF) was determined[24],

$$
\mathrm{K}=\underset{\mathrm{L}^{3}}{\mathrm{~W}} 100
$$

$\mathrm{K}=$ condition factor, $\mathrm{W}=$ total weight $(\mathrm{g})$ and $\mathrm{L}=$ total length $(\mathrm{cm})$.

Diet breath estimates the diet spectrum and was calculated using the diversity index of Shannon-Wiener $(\mathrm{H}) ; \mathrm{H}=-\sum$ pi $\times \ln$ pi Where, pi is the proportion by the number of food type i, Food richness; expressed using Margalef's index: $\mathrm{d}=$ $(\mathrm{S}-1) / \operatorname{logN})$ where $\mathrm{d}=$ Margalef's index, $\mathrm{S}$ is the number of species and $\mathrm{N}$ is the number of individuals[25] and Gut Repletion Index (GRI) which is the percentage of non-empty stomach was estimated[26].

\section{Statistical analysis}

Data collected were collated and analyzed using descriptive statistics (mean, standard deviation and percentage). Statistical comparison of data between and within reaches were carried out using analysis of variance (ANOVA)[27] and line graphs using excel statistical package (2007). Linear regression was employed to determine the type of relationship between any given pairs of variables. Correlation analysis was used to ascertain the significance of these relationships. The variability in data were evaluated using the coefficient of variation (CV) and the $\mathrm{F}$ - ratio test[28].

\section{Results}

Monthly variation in catches revealed that peak catch was biphasic occurring in the early (May-July) and late wet months (November-January) in all the reaches (Figure 2A-B). Catches of the juvenile fish was significantly higher $(p<0.001)$ in the early wet months (May-July).

The maturity curve showed that $50 \%$ of the males matured at $16.5 \mathrm{~cm}$ TL and females at length $14.6 \mathrm{~cm}$ (Figure 3). GSI varied from 8.9 to 20.6 in female fish and from 4.2 to 12.5 in male fish and was higher in the wet season than dry $(p<0.05)$. Monthly changes in the GSI of $C$. gariepinus females and males in consecutive months revealed that both values were very low during September to February and highest in May (Figure 4).
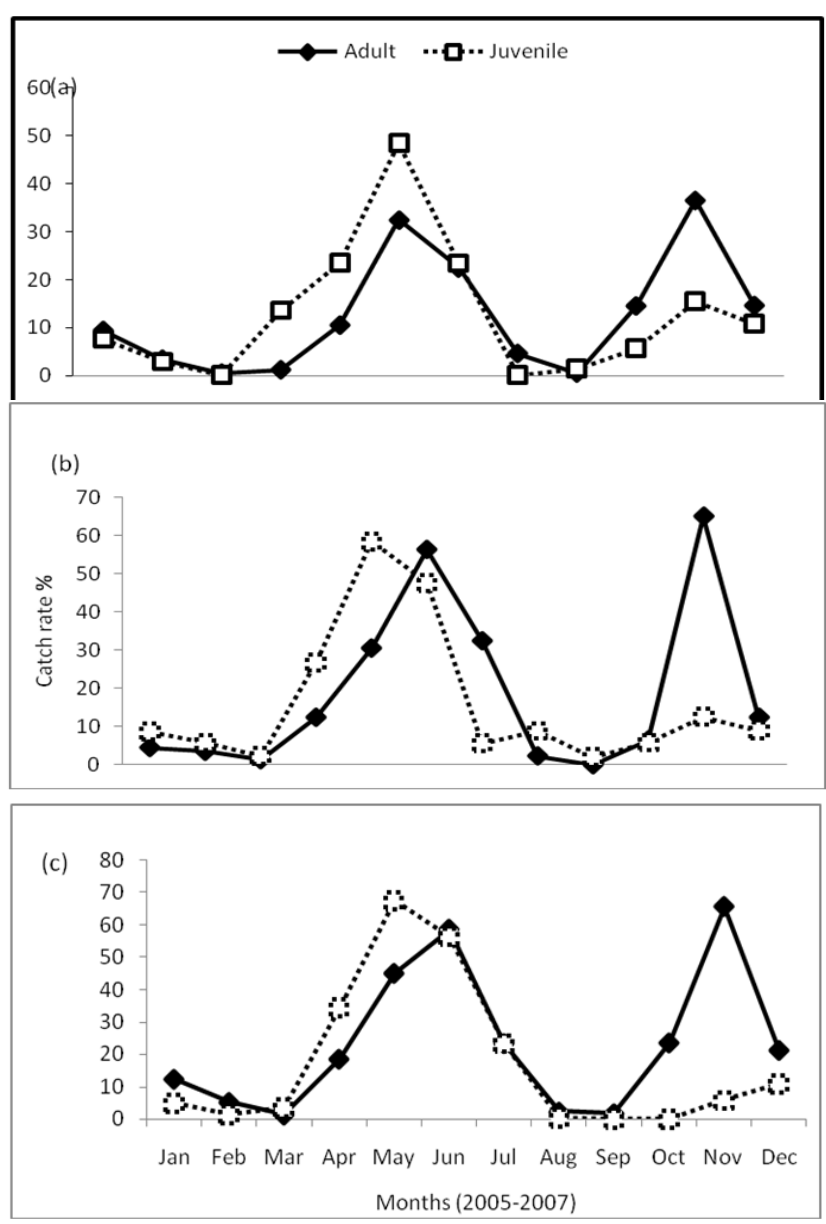

Figure 2. Percentage monthly catch rates of adult and juvenile of gariepinus in the Agbokum waterfalls: (a) upstream, (b) midstream and (c) downstream reaches

Absolute fecundity varied from 12576 and 103,984 while mean fecundity from $12151 \pm 2252$ eggs for fish with SL = $23.8 \mathrm{~cm}$ and weight $167.6 \mathrm{~g}$ in upstream reaches to $56203 \pm 12077$ for fish $\mathrm{SL}=65.9 \mathrm{~cm}$ and weight $=878.8 \mathrm{~g}$ in downstream reaches. Relative fecundity ranged from 339 to 408eggs $\mathrm{g}^{-1}$. Figures $5 \mathrm{~A}$ and $\mathrm{B}$ showed positive and linear relationship between total length, body weight and fecundity indicating that fecundity increase as body size increased. $\mathrm{r}^{2}$ value was 0.657 for total length vs fecundity and 0.876 for body weight vs fecundity.

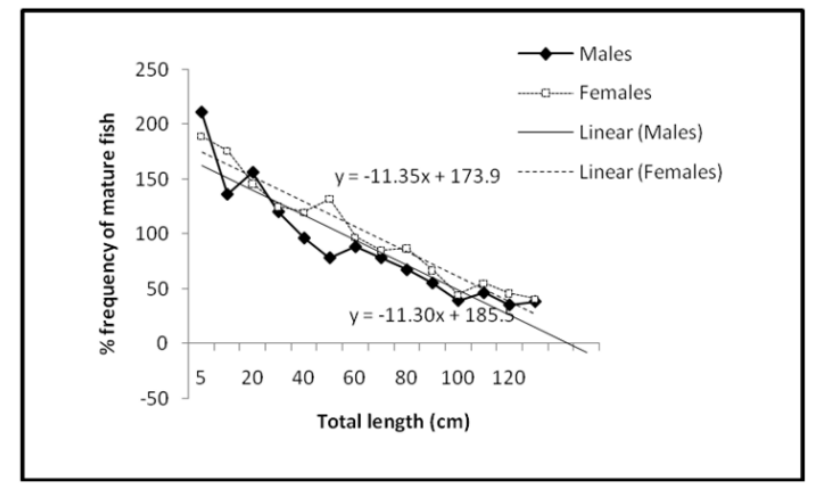

Figure 3. percentage occurrence of mature males and females $C$. gariepinus at different lengths 


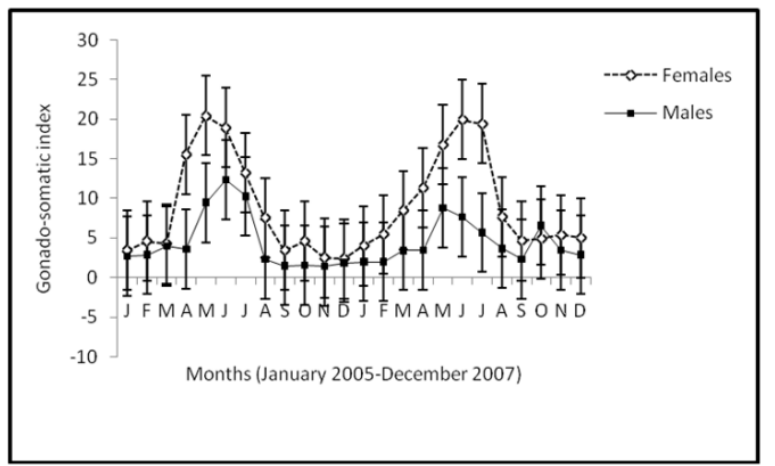

Figure 4. Dynamics in the gonadosomatic index (GSI) of the male and female C. gariepinus in Agbokum waterfalls
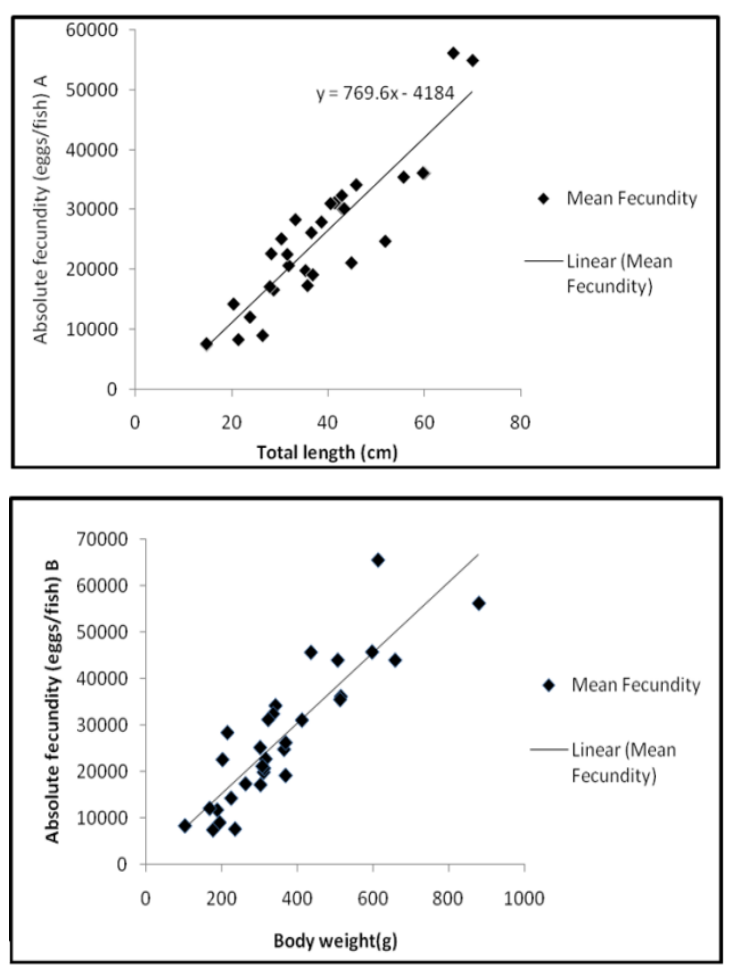

Figure 5. (a) Fecundity-length relationship and (b) fecundity-weight relationship

Table 1. Seasonal changes of frequency of occurrence and composition by number of food items in the stomach of the clarid catfish C. gariepinus in Cross River inland wetlands

\begin{tabular}{|c|c|c|c|c|}
\hline $\mathrm{N}=150$ & \multicolumn{2}{|c|}{ Wet season } & \multicolumn{2}{|c|}{ Dry season } \\
\hline Food items & $\%$ freq of Occurrence & $\%$ composition by number & $\%$ freq of occurrence & $\%$ composition by number \\
\hline Annelid worm & 1.2 & 2.9 & 4.5 & 1.9 \\
\hline Nematode worm Insects & - & - & 7.1 & 1.0 \\
\hline Adult & 7.6 & 4.2 & 9.2 & 15.1 \\
\hline Stages & 9.5 & 12.2 & 10.2 & 13.5 \\
\hline \multicolumn{5}{|l|}{ Crustacean: } \\
\hline Bivalves & 15.2 & 2.9 & 6.4 & 4.3 \\
\hline Gastropods: & 7.2 & 8.4 & 18.0 & 22.3 \\
\hline Decapods: & 18.6 & 7.8 & 20.8 & 24.4 \\
\hline \multicolumn{5}{|l|}{ Fish: } \\
\hline Whole adult fish & 8.4 & 14.6 & - & - \\
\hline Fish juveniles & 29.5 & 21.8 & 4.8 & 6.3 \\
\hline Fish remains & 27.1 & 15.6 & 5.2 & 2.4 \\
\hline Rotifers & 4.8 & 3.5 & - & - \\
\hline Plant materials & 1.3 & 4.6 & 14.8 & 10.5 \\
\hline Food richness & \multicolumn{2}{|c|}{11.2} & \multicolumn{2}{|c|}{8.2} \\
\hline Diet breath $(\mathrm{H})$ & \multirow{2}{*}{\multicolumn{2}{|c|}{$\begin{array}{l}4.7 \\
85 \%\end{array}$}} & \multicolumn{2}{|c|}{0.5} \\
\hline Gut repletion index & & & \multicolumn{2}{|c|}{$85 \%$} \\
\hline
\end{tabular}

$\mathrm{H}=$ Shanon-Wiener diversity index
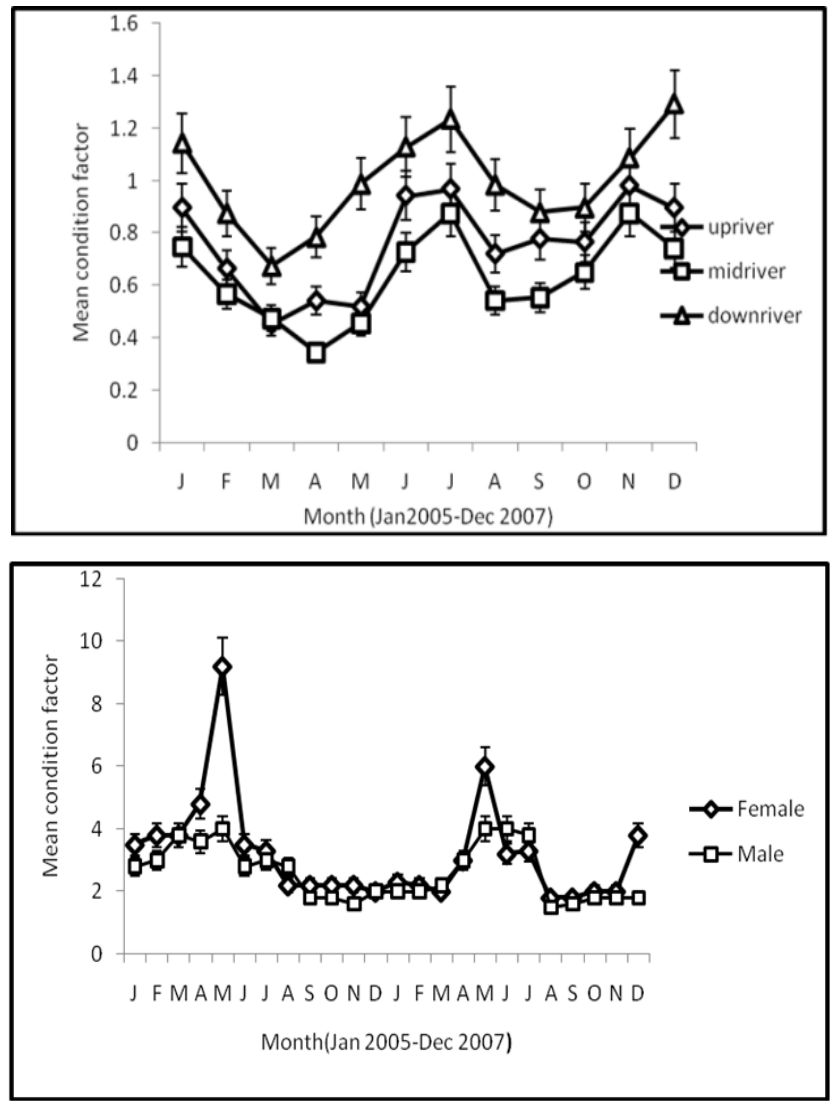

Figure 6. Monthly mean variation of condition factor of male and female C. gariepinus combined from Agbokim waterfalls by (a) reach and (b) sex

Mean condition factor ranged from $0.538 \pm 0.176$ minimum in the upstream reaches to $0.880 \pm 0.204$ maximum at the downstream reaches with significant $(\mathrm{P}<0.05)$ difference between reaches. Also, there was significant monthly variation in the condition factor with both sexes recording highest condition factor between June and July and between November and January. Least values were obtained from February to April and August to October (Figure 6). 
Table 2. Diel variations in the food habits of $C$. gariepinus in the Cross River inland wetlands

\begin{tabular}{|c|c|c|c|c|c|c|c|c|}
\hline No 150 & & & & & & & & \\
\hline \multicolumn{9}{|c|}{ Method } \\
\hline \multicolumn{9}{|c|}{ Frequency of occurrence Numerical } \\
\hline & Day & Night & $\mathrm{X}^{2}$ & $\mathrm{P}$ & Day & Night & $\mathrm{X}^{2}$ & $\mathrm{P}$ \\
\hline Annelid worms & 4 & 45 & 12.7 & $>0.001$ & 23 & 59 & 12.9 & $>0.001$ \\
\hline Nematode worm & 5 & 23 & 10.3 & $>0.001$ & 10 & 56 & 18.3 & $>0.001$ \\
\hline \multicolumn{9}{|l|}{ Insects: } \\
\hline Adult & - & 189 & - & - & - & 387 & - & - \\
\hline Stages & 121 & 311 & 295.8 & $<0.001$ & 524 & 384 & 45.7 & $<0.001$ \\
\hline \multicolumn{9}{|l|}{ Crustacean: } \\
\hline Bivalves & 43 & 98 & 77 & $<0.001$ & 123 & 178 & 139.8 & $<0.001$ \\
\hline Gastropods & 66 & 522 & 206.6 & $<0.001$ & 209 & 432 & 173.6 & $<0.001$ \\
\hline Decapods & 76 & 212 & 167 & $<0.001$ & 87 & 198 & 101 & $<0.001$ \\
\hline \multicolumn{9}{|l|}{ Fish } \\
\hline Whole adult fish & - & 234 & - & - & - & 411 & - & - \\
\hline Fish juveniles & - & 444 & - & - & - & 501 & - & - \\
\hline Rotifers & - & 77 & - & - & - & 132 & - & - \\
\hline Plant materials & 309 & 98 & 111.3 & $<0.001$ & 569 & 189 & 227.4 & $<0.001$ \\
\hline Food richness & 7 & 11 & & & 7 & 11 & & \\
\hline \multirow[t]{2}{*}{ Diet breath $(\mathrm{H})$} & 0.78 & 1.89 & & & 1.23 & 2.78 & & \\
\hline & $67 \%$ & $92 \%$ & & & $67 \%$ & $92 \%$ & & \\
\hline
\end{tabular}

The most frequent food item found in the African catfish in all the reaches were fish prey and fish remains constituting 65 percent of the diet in the wet season and $<10$ percent in the dry season (Table 1). Food objects, habitually, dominating the dry season, included crustaceans, insects, and plant materials, constituting $79 \%$ of the diet. Indices of the diet composition showed that Gut Repletion Index (GRI) was $85 \%$ in both wet and dry season and $67 \%$ and $92 \%$ in the day and night, respectively. The least prey diversity was found in dry season diet $(\mathrm{H}=4.7$ and 0.5 for wet and dry seasons respectively). Diel pattern in the consumption of food items by $C$. gariepinus showed eleven food types ingested during the night while seven types were taken during the day (Table 2 ). The occurrence of all items except plant materials was significantly higher $(\mathrm{P}<0.05)$ in the night catches than the day.

\section{Discussion}

The seasonal variation in the catch rate of Clarias gariepinus as indicated in the analysis of variance support the notion that various fish communities show non-random patterns in composition over time[29, 30]. Seasonal variation in catch rate may be as result of the period of courtship, during which and resting take place and the species withdraws to suitable and safe areas for spawning[31]. Peak of GSI for this species in April-May was confirmed by the largest frequency of the matured phases during this period; characterizing a single annual spawning, and synchronic ovarian development. By June/July, spawning was over, as indicated by the decrease in GSI and the presence of freshly spent ovaries. It has been reported[32] that the final trigger of spawning in Clarias species is caused by a rise in water level due to rainfall; which commenced in the study area between
April and June[33, 34] all found out that in some localities catfishes present a single annual spawning period corresponding to the late dry season or early wet season, associated with high water temperature. Our findings indicate that, for captive breeding programs gravid fishes are available in the wild during April-August. During October to January most ovaries were spent, indicating that the spawning period was over. Therefore, from the point of view of fisheries management the best fishing period for the species in the Agbokom waterfalls is October- January because gravid fish are almost absent during the period. Although the juveniles are abundant during the period, with the use of appropriate fishing methods and management practices such as regulated mesh size ( $>62.8 \mathrm{~mm}$ stretched mesh), juvenile overfishing could be avoided, and only the table sizes will be harvested. A closed season, or less intense fishing, during April to September, when gravid C. gariepinus are abundant, would help to conserve the natural stocks, by allowing the fish to breed at least once in their lifetime.

The relative fecundity range of 453-678 eggs $\mathrm{cm}^{-1}$ recorded in this study was comparatively high compared to observations from other clariid catfishes. 308-403 eggs cm${ }^{-1}$ from C. gariepinus had been recorded in Hardap dam, Namibia[8] and 203-278 eggs $\mathrm{cm}^{-1}$ in Cross River[35] while 443-498 eggs $\mathrm{cm}^{-1}$ were reported in Opa reservoir, Nigeria[9]. This shows that $C$. gariepinus in waterfalls may be more fecund than those in other fresh water bodies. Peak season in fecundity of these species which coincides with onset of rains and the rising flood have also been observed in the River Niger[36, 37, 38]. All concluded that most tropical fishes breed on the rising flood thus allowing the juveniles to take full advantage of the flooded banks for feeding, while being protected from predation. There are indications that the intensity of flooding influences the reproductive success as stronger year classes have been noted from those years 
when particularly intense floods occur in the Kafue River and the Central Delta of the Niger, Senegal and Lake Chad (Stauch, Kainji Research Institute, Nig.( pers. comm.)

Our data show that condition factor is highly correlated with GSI. However, with higher GSI the weight for length is bound to increase, irrespective of whether or not the food organisms are in good or bad condition. The higher condition factor obtained between June and July, and low values between August and October, marched findings reported[34] and the results attributed to spawning activities, which may have resulted from the

accumulation of fats and ripe gonads carried by the mature adult females. The observation that $62 \%$ of the samples examined had condition factor above mean showed that the majority of fish in the population are in excellent condition[39].

The diet composition showed C. gariepinus to be an omnivorous predatory fish. The diet spectrum in which fish prey and crustaceans were the most abundant, could be closely marched with that obtained in Clarias gariepinus from Ubangui River, Central African Republic[40], in Lake Sibaya, South Africa[41], in Lake Kinneret, Israel[42] and in Southern Florida[43]. There is considerable seasonal variation in the feeding activity correlated with flood regime. During floods the release of nutrients, rapid growth of vegetation and the increased availability of other sources such as seeds, young shoots, leaves and molluscs form the basis for a particularly intense feeding activity[44]. The diet generally reflects the seasonal distribution of macro-invertebrates and fish prey in the environment $[45,46]$. Presence of plant materials in the diet of this species had been reported $[47,48]$ and it was suggested that the frequent occurrence, especially during dry season, could be a survival strategy in times of scarcity of prey. The gut repletion index of 85 percent indicates that the fish is a regular feeder. High values of other indices such as Food Richness and Diet breadth showed that the species exhibits trophic flexibility, an ecological advantage that enabled the fish to switch from one food category to another in response to fluctuation in their abundance[49].

The diel pattern of feeding, where C. gariepinus completely ignored fish prey during the day and fed mainly on invertebrates and plants, was also observed[41]. He attributed this behavior to its inability to catch prey fish in daylight due to its slow, methodical, predatory tactics. The generally higher diet indices recorded from night catches in this study had also been reported[43] and suggested that the species is more active at night.

\section{Conclusions}

The species exhibits trophic flexibility, an ecological advantage that enabled the fish to switch from one food category to another in response to fluctuation in their abundance. Majority of fish in the population are therefore in excellent condition. A closed season, or less intense fishing, during
April to September, when gravid C. gariepinus are abundant, would help to conserve the natural stocks, by allowing the fish to breed at least once in their lifetime.

\section{ACKNOWLEDGEMENTS}

The authors are grateful to Senate of Cross River University of Technology, Nigeria for the Grant to support in this project.

\section{REFERENCES}

[1] Teugels, G. G., 1986a, A systematic revision of the African species of the genus Clarias (Pisces: Clariidae) Museum Africa Centre, Belgium. pp3-72

[2] Haruna B. G., 2003, Sex ratio and fecundity of Clarias gariepinus in Opa Reservoir, Ile-Ife, Nigeria. Proceeding of annual conference of Fish Soc Nigeria Proc. FISON, 12(7), 122-130.

[3] Teugels, G.G. 1982, Prelimnary data of a systamatic outline of the African species of Genus Clarias (Pisces: Clariidae), J. Nat. Hist. 95, 11-28.

[4] van den Bossche, J.P. and Bernacsek, G. M., 1990, Source book for the inland fishery resources of Africa. 2. CIFA Technical Paper 18.2, FAO, Rome Italy, p411

[5] Aluko, P. O. and Shaba, M. 1999, Intra- and inter-specific hybridization studies between exotic Clarias gariepinus and two indigenous Clariid species. Nigerian J. Gen. 14, 59-63.

[6] Viser, S. A. 1970, Kainji, a Nigerian man-made lake. Kainji Lake studies. Nigerian Inst Soc Econ Res, Ibadan. p126.

[7] Gaigher, I. G., 1977, Reproduction in the catfish (Clarias gariepinus) in the Hardap dam,South West Africa. Madoqua 10: $52-59$

[8] Abayomi, R. E. and Arowomo A. F., 1996, Sex ratio and fecundity of Clarias gariepinus in Opa Reservoir, Ile-Ife, Nigeria. Proceeding of annual conference of Fish Soc Nigeria Proc. FISON, 12(7), 122-130.

[9] Ugumba, O. A. and Ugumba, A. A., 1988, Induced ovulation, artificial spawning, survival and early growth of larvae of the African catfish, C. gariepinus. In:Otubusin SO, Ezeri GNO,

[10] Machiels, M. A. M, Herken, A. M., 1985, Growth rate, feed utilization and energy metabolism of the African catfish Clarias gariepinus as affected by protein and energy content. Aquacult 46,19-23

[11] Ayinla P.O. and Nwadukwe, D.Y. 1999, On length-weight relationship. Fishbyte section 5, 11-13.

[12] Fagbenro, O. A., 1993, Studies on the biology and aquaculture potential of feral catfish Heterobranchus bidorsalis (Geoffrey St. Hilaire 1809) (Clariidae). Trop. Zool. 6, 67-79

[13] Teugels, G. G., Reid, G. Mc. G. and King, R. P., 1992, Fishes of the Cross River Basin (Cameroon - Nigeria). Taxonomy, Zoogeograhpy, Musee Royal Del Afrique-Centrale, Tevuren, 
Belgique. Ann Sci Zoolog 260:132.

[14] Fischer, W., and Bianchi, G., 1984. Species identification sheets for fishery area. FAO, Rome, pp34-47

[15] Idodo-Umeh, G., 2003, Fresh water fishes of Nigeria. Taxonomy, ecological notes, diets and utilization. Idodo-Umeh Publishers Limited. p232

[16] Olaosebikan, B. D. and Raji, A., 1988, Field guide to Nigerian freshwater fishes. Federal College of Freshwater Fishes (FCFF), New Bussa, Niger State, Nigeria. 106pp.

[17] Holden, M. and Reed, W., 1972, West African fresh water fish. Longman Group Ltd, London, 68pp.

[18] Buije, A.D. and Houthuijzen, R. P., 1992, Piscivory, growth, and size- selective mortality of age 0 pikeperch (Stizostedion lucioperca). Can. J. Fish. Aquat. Sci., 49, 894 - 902.

[19] Windell JT and Bowen M (1978) Food analysis and weight of digestion met hod of studying food consumed. In: Bagenal T (ed) Fish production in fresh water. Oxford. pp197-201.

[20] Hyslop, E. J. 1980, Stomach content Analysis: A review of methods and their application. J. Fish. Biol. 17,111-129.

[21] Simpson, A.C., 1951, The fecundity of plaice. U.K. Ministry of Agriculture and Fish Food Invest Serv 217: 3-27.

[22] June, F. C. 1953, Spawning of yellwfin tuna in Hawaiian waters. Fishery Bulletin 54,47 -61.

[23] Ricker, W.E. 1975. Computation and interpretation of biological statistics of fish populations. Bull. Fish. Res. Bd. Can. 191: 209-210.

[24] Andrews D. G. and Matsuda O.U., 1975, Length-weight parameters and condition factor of two West African prawsn. Rev. Hydrobiol. Trop. 27 (2), 121-129.

[25] Hynes, H. B. N., 1970, The ecology of running waters. Liverpool, Liverpool University press. $555 \mathrm{pp}$.

[26] Steel, R.G.D, Torrie, J. H. 1980, Principles and procedures of statistics. NewYork McGraw Hill Book company. New York p 063.

[27] Lewontin,R.C.1966, On the measurement of relative variability. System Zool 15, 141- 142.

[28] Jackson, D. A, Harvey, H. H, 1997, Quantitative and qualitative sampling of lake fish communities. Can. J. Fish Aquat. Sci. 54, 2807-2813.

[29] Connor, E. F., Simberloff, D. 1979, The assemblage of species communities. Ecol60,11- 32.

[30] Bruton, M. N. 1979a, The breeding biology and early development of Clarias gariepinus in Lake Sibaya, South Africa. Trans. Zool Soc London 35, 1-45.

[31] De Graaf J. G., Galemoni F. and Banzoussi B. 1995, Recruitment control of Nile tilapia, Oreochromis niloticus, by the African catfish, Clarias gariepinus. Aquaculture Research
$30,25-36$.

[32] Dmitincko, E. M. 1970, Reproduction of the sea catfish (Arius thalassinus, Ruppel) in the Arabian sea. J Appl Ichthyol 10, 361-364.

[33] Rimmer, M. A. and Merrick, J. R. 1983, A review of the reproduction and development in the fork-tailed catfishes (Ariidae). J Limn Soc London 107, 41-50.

[34] Offem, B. O., Akebgejo-Samsons, Y. and Omoniyi, I. T., 2010, Aspects of ecology of Clarias anguillaris (Teleostei: Clariiae) in the Cross River, Nigeria. Turk J Fish and Aquat Sci. 10, 101-109.

[35] van der Waal B. C. W., 1975, Observations on the breeding habits of African catfish, Clarias gariepinus (Burchell). J. Fish Biol. 48, 6-10.

[36] Harding, D., 1966, Lake Kariba: the hydrology and development of fisheries. In: Lowe McConnell RH (ed) Manmade lakes. Academic Press, London, pp65-66

[37] Blache, J. 1964, Les poissons du Basin de Tchad et du Basin adjacent du mayo kabbi. Etude systematique et biologioue, Tome. ORSTROM 4,11483

[38] Fagade, S. O., Adebisi, A. A. and Atanda, A. N., 1984, The breeding cycle of Clarias lazera.Hydrobiol. 100, 493-500.

[39] Micha, J. C. 1973, Etude des populations piscecoles de I'Ubangui et tentative de selection et d'adaptation dequelques especes a l'etang de pisciculture. Centre Technique Forestiere Tropical, Nogent Sur Marne, p100

[40] Spatura, P., Viveen, W. J. A. R. and Gophen, M. 1987, Food composition of Clarias gariepinus in lake Kinneret, Israel. Hydrobiol. 144, 17-23.

[41] Robbins, H. R. 2004, Description: walking catfish - Clarias batrachus. US Geological Survey, Florida, p7.

[42] Blache, J. 1964. les pessions du basin du Tchad et du basin adjacent du mayo kebbi. Men ORSTOM 4.2 : 48 3pp.

[43] Wooton, R. J., 1979, The effect of size of food ration on egg production in the femalethree-spined stickleback,Gasterosteu s aculeatus. J Fish Biol 5:89-96.

[44] Madu, C.T., Fodike, E. B. C and Ita. F. 1991, Food and feeding habits of hatchlings and the mudfish Clarias gariepinus. J Aquat Sci 5: 27-32.

[45] Courtenay, W.R., 1970, Florida's walking catfish. Words Nat Sci Bull 10, 1-6.

[46] Courtenay, W. R., Sahlman, W. W., Miley, I. I. and Herema, D.J., 1974, Exotic fishes in fresh and brackish waters of Florida. Biol. Conserv. 6, 294-340.

[47] Clay, D. 1979, Population biology, groth and feeding of African catfish, Clarias gariepinus, with special reference to juveniles and their importance to fish culture. Hydrobiol 87, 453-487. 